\title{
Simultaneous selection Indices in exotic Genotypes of Italian millet [Setaria italica (L.) Beauv]
}

\author{
P. Lakshmi Prasanna, J.S.V. Samba Murthy, P.V. Rama Kumar and \\ V. Srinivasa Rao \\ Department of Genetics and Plant Breeding, Agricultural College, Bapatla 522101, Andhra Pradesh state, \\ country-India
}

\begin{abstract}
Selection indices are useful in understanding the extent of improvement that can be effected in yield by combination of characters. It forms the basis in considering the correlated characters for higher efficiency in selection for yield. Keeping the above points in view, study on classical selection indices in 34 exotic genotypes of Italian millet carried out for 13 characters during kharif and rabi. Among exotic group of genotypes, GS 462, GS 489 and GS 488 for kharif and GS 462, GS 463 and GS 458 for rabi are to be favoured. In general, the indices, which include more than one character, gave high genetic advance suggesting the utility of selection index for simultaneous improvement of several characters. It was observed that inclusion of characters one by one in the function gave fluctuating changes in the value of genetic advance and relative efficiencies over yield. A selection index of eight characters combination i.e. grain yield per plant, days to $50 \%$ flowering, plant height, number of productive tillers per plant, ear weight, carotene, 1000 grain weight and crude protein content had recorded high genetic advance and relative efficiency over grain yield per plant alone during kharif where as selection index of nine characters combination i.e. grain yield per plant, days to $50 \%$ flowering , plant height, number of productive tillers per plant, ear length, ear weight, 1000 grain weight, crude protein content and calcium content had recorded high genetic advance and relative efficiency over grain yield per plant alone during rabi. These classical selection indices may be given due weightage for simultaneous improvement in the respective groups.
\end{abstract}

Key words: Italian millet, selection indices, Seteria italica, classical selection

Submitted Date 27 June 2013

Accepted Date: 02 July 2013

\section{Introduction}

Selection of plants indiscriminately from a field on the basis of phenotypic expressions might lead to disappointing results. It is not the phenotypic character but the genotypic value that should be accounted to form the basis for selecting plants. Thus, index based on economic characters should give weight age to the phenotypic expression in terms of genotype by eliminating environmental variation (Panse, 1949). The adoption of discriminant function solves the problem of apportioning the total effect by discriminating environmental effect and also by assigning relative weights to each of the yield components based on its genotypic contribution (Panse,1957).

When selection is applied to the improvement of economic value of a plant, it is generally applied to several characters simultaneously and not just to one, because economic value depends on more than one character. This is usually referred to as multiple trait selection. The method that is expected to give more rapid improvement of economic value, however is to apply selection simultaneously to all the component characters together by giving appropriate weights to each character (Falconer,1964).

Foxtail millet ranks second in the world's total production of millets. It is generally raised as rain fed crop in India. It is usually cooked whole or made into meal or into beer. It can also make useful hay or silage. In addition foxtail millet is consumed as stiff porridge called sargati, or as leavened bread known as roti, after the dehulled grain has been milled into flour. Foxtail millet with a short growing period is grown extensively in diverse agro- climatic regions for grain and fodder. It is known for its drought tolerance and is an indispensable crop of vast rain fed areas in semi-arid regions of India. It is also grown in nutrient deficient soils and possesses tolerance to pests and diseases. The grain is a good source of protein and contains $\beta$-carotene. Italian millet grain possesses $12.3 \%$ protein, $4.7 \%$ fat, $60.6 \%$ carbohydrates and $3.2 \%$ ash.

\section{Material And Methods:}

The present investigation was undertaken at Agricultural College Farm, Bapatla, Guntur (Dt.), Andhra Pradesh with the 34 exotic genotypes of Italian millet [Setaria italica (L.) Beauv] procured from collections maintained at All India Co-ordinated Small Millets Improvement Project (AICSMIP), Bengaluru. The studies were carried out separately during two seasons of 2008-2009, namely kharif 2008 and rabi 2009. The genotypes 
are sown separately in randomized block design with four replications. Each genotype was sown in four rows of $5 \mathrm{mts}$ length spaced at $25 \times 10 \mathrm{~cm}$ apart. Data were collected on 10 randomly tagged competitive plants per genotype per replication for number of productive tillers per plant, plant height, flag leaf area, ear length, ear weight, straw weight, grain yield. However data on days to $50 \%$ flowering, days to maturity, grain protein $\%$, calcium content and grain $\beta$-carotene were recorded on plot basis. The genetic worth $(\mathrm{H})$ of genotypes was calculated as defined by Smith (1936). The expected genetic advance, by constructing different discriminant functions was calculated and relative efficiency of each discriminant function was estimated as per Brim et al. (1959).

\section{Results And Discussion:}

The economic weights $\left(a_{i}\right)$ and weighing coefficient $\left(b_{i}\right)$ values given for different characters embodied in Table 1. Selection criterion values for the both seasons are presented in Table 2. Results of Selection Indices constructed using Fisher's discriminant function during both seasons presented in tables 3 and 4.

The trait carotene(4.86) recorded highest $\mathrm{a}_{\mathrm{i}}$ value followed by 1000 grain weight $(0.61)$ and ear weight(0.44) during kharif where as in rabi carotene(4.25) followed by 1000 grain weight(0.38) and calcium content (0.24). Least $\mathrm{a}_{\mathrm{i}}$ value (0.01) recorded by days to maturity during kharif and plant height, days to maturity and flag leaf area in rabi.

In these genotypes, carotene(4.4713) recorded highest $b_{i}$ value followed by number of productive tillers per plant (0.6715) and 1000 grain weight(0.5807) during kharif where as in rabi carotene(3.7427) followed by 1000 grain weight $(0.3381)$ and calcium content $(0.2381)$. Least $b_{i}$ values recorded by plant height $(0.0161)$ and days to maturity (0.0117) during kharif where as in rabi plant height $(0.0082)$ and days to $50 \%$ flowering (0.0095).

Selection criterion during kharif and rabi are presented in Table 3. Among exotic group of genotypes, during kharif high values were observed for GS 462(17.66) followed by GS 489(16.38), GS 488(16.31) while during rabi 2009 in genotypes GS 462(16.67) followed by GS 463(16.49), GS 458(15.39).

When several traits influence the net worth of an organism it is essential to know the proportionate contribution of the characters, if maximum progress under selection is made (Hazel and Lush, 1942). It might sometimes be possible to get more rapid progress under selection for a correlated response than for selection for the desired character itself (Lerner, 1950).

In exotic genotypes, eight characters i.e. grain yield per plant, days to $50 \%$ flowering, plant height, number of productive tillers per plant, ear weight, carotene, 1000 grain weight and crude protein content during kharif where as nine characters i.e. grain yield per plant, days to $50 \%$ flowering, plant height, number of productive tillers per plant, ear length, ear weight, 1000 grain weight, crude protein content and calcium content during rabi together formed efficient selection indices and these traits may be useful for simultaneous improvement in the respective groups. It was observed that inclusion of characters one by one in the function gave fluctuating changes in the value of genetic advance and relative efficiencies over yield

Robinson et al. (1951) reported in corn that when economic characters were considered the progress measured in terms of yield alone will be greater. In the present study inclusion of characters one by one in the function gave almost the similar changes in genetic advance in both groups. Similar results were earlier reported by Shankar et al.(1963), Mahadevappa et al. (1965), Gian Singh(1974), Dhagat et al. (1977), Mishra et al. (1983), Basavaraja and sheriff (1992) Bhat and Shariff (1994).

\section{Conclusions:}

Among exotic group of genotypes, GS 462, GS 489 and GS 488 for kharif and GS 462, GS 463 and GS 458 for $r a b i$ are to be favoured In general, the indices, which include more than one character, gave high genetic advance suggesting the utility of selection index for simultaneous improvement of several characters. It was observed that inclusion of characters one by one in the function gave fluctuating changes in the value of genetic advance and relative efficiencies over yield. A selection index of eight characters combination i.e. grain yield per plant, days to $50 \%$ flowering, plant height, number of productive tillers per plant, ear weight, carotene, 1000 grain weight and crude protein content had recorded high genetic advance and relative efficiency over grain yield per plant alone during kharif where as selection index of nine characters combination i.e. grain yield per plant, days to $50 \%$ flowering, plant height, number of productive tillers per plant, ear length, ear weight, 1000 grain weight, crude protein content and calcium content had recorded high genetic advance and relative efficiency over grain yield per plant alone during rabi

\section{Acknowledgements:}

I am thankful to $A N G R A U$ for providing financial assistance in the form of fellowship during my course of study. 


\section{References:}

[1]. Panse V. G. A discriminant function for selection of yield in cotton. Indian Cotton Growing. Rew. 1949,111

[2]. Panse V. G. 1957. Genetics of quantitative characters in relation to plant breeding. Indian Journal of Genetics and Plant Breeding. $17,1957,318-328$

[3]. Falconer D. S. An Introduction to Quantitative Genetics. Second edition. Oliver and Boyd Ltd., Edinburgh .1964, $312-324$.

[4]. Smith H. F.A discriminant function for plant selections. Annals of Eugenics. 7, 1936,40-250.

[5]. Brim C. A., Johnson H. W., Cockerham C. C. Multiple selection in soyabeans. Agronomy Journal 51, 1959, 42-46.

[6]. Hazel L. N and Lush J. L. The efficiency of three methods of selection. Journal of Heredity. 23, 1942, $293-339$.

[7]. Lerner I. M.Population genetics and Animal improvement. Cambridge University Press. XVIII. $1950,342$.

[8]. Robison H. F., Comstock, R. E and Harvey, P. H. Genotypic and phenotypic correlation in corn and their implication in selection. Agronomy Journal. 43, 1951, 262-267.

[9]. Shankar K. The use of selection indices in the improvement of a pearl millet population. Indian Journal of Genetics. 23 (1), 1963, 30-33.

[10]. Mahadevappa M and Ponnaiya B. W. X. A discriminant function for selection for yield in Eleusine coracana Gaertn. Madras Agricultural Journal. 1965, 47-5.

[11]. Gian Singh Variability in kangni-3, Association between plant characters and discriminant function for varietal selection in four environments. Indian Journal of Genetics and Plant Breeding. 34(2), 1974, 411-416.

[12]. Dhagat N. K., Goswami U and Narsighani G. Character correlation and selection indices in Italian millet. Indian Journal of Agricultural Sciences. 47(12), 1977, 599-603.

[13]. Dhagat N. K., Goswami U and Narsighani G. Character correlation and selection indices in Italian millet. Indian Journal of Agricultural Sciences. 47(12),1977, 599-603.

[14]. Mishra P. K and Patnaik, M. C. Evaluation of selection indices in Ragi. Mysore Journal of Agricultral Sciences. 17,1983, $22-25$.

[15]. Basavaraj G. T. and Sheriff R. A. Formulation of selection indices in finger millet (Eleusine coracana). Indian Journal of Genetics. 52(2),1992, 199-202

[16]. Bhat B. V. and Sheriff, R. A. Selection criterion in finger millet (Eleusine coracana Gaertn.) Mysore Journal of Agricultural Sciences. 28(1), 1994, 5-7.

Table 1 : Economic weights $\left(a_{i}\right)$ and weighing coefficients $\left(b_{i}\right)$ for different characters in exotic genotypes during kharif 2008 and rabi 2009 in Italian millet [Setaria italica (L.) Beauv]

\begin{tabular}{|l|c|c|c|c|}
\hline \multirow{2}{*}{ Character } & \multicolumn{2}{|c|}{$\begin{array}{c}\text { Economic weights } \\
\left(\mathbf{a}_{\mathbf{i}}\right)\end{array}$} & \multicolumn{2}{c|}{$\begin{array}{c}\text { Weighing coefficients } \\
\left(\mathbf{b}_{\mathbf{i}}\right)\end{array}$} \\
\cline { 2 - 5 } & $\begin{array}{c}\text { kharif } \\
\mathbf{2 0 0 8}\end{array}$ & $\begin{array}{c}\text { rabi } \\
\mathbf{2 0 0 9}\end{array}$ & $\begin{array}{c}\text { kharif } \\
\mathbf{2 0 0 8}\end{array}$ & rabi 2009 \\
\hline Days to 50\% flowering & 0.02 & 0.02 & 0.0275 & 0.0095 \\
\hline Plant height(cm) & 0.02 & 0.01 & 0.0161 & 0.0082 \\
\hline Days to maturity & 0.01 & 0.01 & 0.0117 & 0.0259 \\
\hline $\begin{array}{l}\text { Number of productive tillers/ } \\
\text { plant }\end{array}$ & 0.34 & 0.09 & 0.6715 & 0.0915 \\
\hline Flag leaf area(cm $\left.{ }^{2}\right)$ & 0.04 & 0.01 & 0.0347 & 0.0138 \\
\hline Ear length $(\mathrm{cm})$ & 0.11 & 0.05 & 0.1152 & 0.0492 \\
\hline Ear weight $(\mathrm{g})$ & 0.44 & 0.20 & 0.4883 & 0.2310 \\
\hline Straw weight $(\mathrm{g})$ & 0.05 & 0.02 & 0.0623 & 0.0262 \\
\hline 1000 grain weight $(\mathrm{g})$ & 0.61 & 0.38 & 0.5807 & 0.3381 \\
\hline Carotene $(\mathrm{mg} / 100 \mathrm{~g})$ & 4.86 & 4.25 & 4.4713 & 3.7427 \\
\hline Crude protein $(\%)$ & 0.14 & 0.11 & 0.1330 & 0.0970 \\
\hline Calcium content $(\mathrm{mg} / 100 \mathrm{~g})$ & 0.31 & 0.24 & 0.3132 & 0.2381 \\
\hline Grain yield/ plant $(\mathrm{g})$ & 0.16 & 0.03 & 0.0630 & 0.0282 \\
\hline
\end{tabular}


Table 2: Selection criterion values for exotic genotypes in Italian millet [ Setaria italica (L.) Beauv] in classical selection indices.

\begin{tabular}{|c|c|c|c|}
\hline S.No & Genotypes & kharif 2008 & rabi 2009 \\
\hline 1 & GS 454 & 13.46 & 13.74 \\
\hline 2 & GS 455 & 14.31 & 11.17 \\
\hline 3 & GS 456 & 14.01 & 11.84 \\
\hline 4 & GS 457 & 13.72 & 13.11 \\
\hline 5 & GS 458 & 14.93 & 15.39 \\
\hline 6 & GS 459 & 14.54 & 14.88 \\
\hline 7 & GS 461 & 14.90 & 14.19 \\
\hline 8 & GS 462 & 17.66 & 16.67 \\
\hline 9 & GS 463 & 14.81 & 16.49 \\
\hline 10 & GS 464 & 14.24 & 12.12 \\
\hline 11 & GS 465 & 14.29 & 11.03 \\
\hline 12 & GS 467 & 14.52 & 11.67 \\
\hline 13 & GS 469 & 11.79 & 14.08 \\
\hline 14 & GS 470 & 13.22 & 12.06 \\
\hline 15 & GS 472 & 13.27 & 11.19 \\
\hline 16 & GS 473 & 14.11 & 12.38 \\
\hline 17 & GS 474 & 11.73 & 12.11 \\
\hline 18 & GS 475 & 13.74 & 15.01 \\
\hline 19 & GS 476 & 13.26 & 12.99 \\
\hline 20 & GS 477 & 16.17 & 12.22 \\
\hline 21 & GS 478 & 14.46 & 12.72 \\
\hline 22 & GS 479 & 13.13 & 14.80 \\
\hline 23 & GS 480 & 14.13 & 14.74 \\
\hline 24 & GS 481 & 11.57 & 13.45 \\
\hline 25 & GS 482 & 12.18 & 14.43 \\
\hline 26 & GS 484 & 11.36 & 11.57 \\
\hline 27 & GS 485 & 12.30 & 11.78 \\
\hline 28 & GS 486 & 15.32 & 14.17 \\
\hline 29 & GS 487 & 15.75 & 14.23 \\
\hline 30 & GS 488 & 16.31 & 13.88 \\
\hline 31 & GS 489 & 16.38 & 13.35 \\
\hline 32 & GS 490 & 14.67 & 11.74 \\
\hline 33 & GS 491 & 13.59 & 11.56 \\
\hline 34 & GS 492 & 11.84 & 12.79 \\
\hline
\end{tabular}

Table 3: Selection indices for different character combinations in exotic genotypes of Italian millet [Setaria italica (L.) Beauv] during kharif 2008.

\begin{tabular}{|c|c|c|c|}
\hline S.No. & Character Combination & $\begin{array}{c}\text { Genetic } \\
\text { Advance }\end{array}$ & $\begin{array}{l}\text { Relative efficiency } \\
\text { over grain } \\
\text { yield/plant } \\
\end{array}$ \\
\hline 1 & Grain Yield per plant $(\mathrm{g})\left(\mathrm{X}_{1}\right)$ & 2.92 & 100.00 \\
\hline 2 & Days to $50 \%$ flowering $\left(\mathrm{X}_{2}\right)$ & 1.65 & 56.76 \\
\hline 3 & Plant height $(\mathrm{cm})\left(\mathrm{X}_{3}\right)$ & 5.07 & 173.75 \\
\hline 4 & $\begin{array}{l}\text { Number of productive tillers per } \\
\text { plant }\left(X_{4}\right)\end{array}$ & 0.52 & 17.90 \\
\hline 5 & Ear length $(\mathrm{cm})\left(\mathrm{X}_{5}\right)$ & 1.74 & 59.70 \\
\hline 6 & Ear weight $(\mathrm{g})\left(\mathrm{X}_{6}\right)$ & 0.46 & 15.86 \\
\hline 7 & Carotene $(\mathrm{mg} / 100 \mathrm{~g})\left(\mathrm{X}_{7}\right)$ & 0.39 & 13.35 \\
\hline 8 & 1000 grain weight $(\mathrm{g})\left(\mathrm{X}_{8}\right)$ & 0.07 & 2.42 \\
\hline 9 & $\begin{array}{l}\text { Crude protein percent } \\
(\mathrm{mg} / 100 \mathrm{~g})\left(\mathrm{X}_{9}\right)\end{array}$ & 1.07 & 36.71 \\
\hline 10 & Calcium content $(\mathrm{mg} / 100 \mathrm{~g})\left(\mathrm{X}_{10}\right)$ & 1.29 & 44.10 \\
\hline 11 & $\mathrm{X}_{3} \mathrm{X}_{4}$ & 7.13 & 244.45 \\
\hline 12 & $\mathrm{X}_{2} \mathrm{X}_{5} \mathrm{X}_{6}$ & 8.35 & 286.44 \\
\hline 13 & $\mathrm{X}_{2} \mathrm{X}_{3} \mathrm{X}_{5} \mathrm{X}_{6}$ & 8.78 & 301.29 \\
\hline 14 & $\mathrm{X}_{2} \mathrm{X}_{3} \mathrm{X}_{4} \mathrm{X}_{6} \mathrm{X}_{7}$ & 9.11 & 312.54 \\
\hline 15 & $\mathrm{X}_{2} \mathrm{X}_{3} \mathrm{X}_{4} \mathrm{X}_{6} \mathrm{X}_{7} \mathrm{X}_{8}$ & 9.38 & 321.59 \\
\hline 16 & $\mathrm{X}_{1} \mathrm{X}_{2} \mathrm{X}_{3} \mathrm{X}_{4} \mathrm{X}_{6} \mathrm{X}_{7} \mathrm{X}_{8}$ & 9.58 & 328.48 \\
\hline 17 & $\mathrm{X}_{1} \mathrm{X}_{2} \mathrm{X}_{3} \mathrm{X}_{4} \mathrm{X}_{6} \mathrm{X}_{7} \mathrm{X}_{8} \mathrm{X}_{9}$ & 9.62 & 330.07 \\
\hline 18 & $\mathrm{X}_{1} \mathrm{X}_{2} \mathrm{X}_{3} \mathrm{X}_{4} \mathrm{X}_{6} \mathrm{X}_{7} \mathrm{X}_{8} \mathrm{X}_{9} \mathrm{X}_{10}$ & 9.61 & 329.81 \\
\hline 19 & $\mathrm{X}_{1} \mathrm{X}_{2} \mathrm{X}_{3} \mathrm{X}_{4} \mathrm{X}_{5} \mathrm{X}_{6} \mathrm{X}_{7} \mathrm{X}_{8} \mathrm{X}_{9} \mathrm{X}_{10}$ & 9.58 & 328.70 \\
\hline
\end{tabular}


Simultaneous selection Indices in exotic Genotypes of Italian millet [Setaria italica (L.) Beauv]

Table 4: Selection indices for different character combinations in exotic genotypes of Italian millet [Setaria italica (L.) Beauv] during rabi 2009.

\begin{tabular}{|l|l|l|l|}
\hline S.No & Character Combination & Genetic Advance & $\begin{array}{l}\text { Relative } \\
\text { efficiency over } \\
\text { grain yield/plant }\end{array}$ \\
\hline 1 & Grain Yield per plant $(\mathrm{g})\left(\mathrm{X}_{1}\right)$ & 12.14 & 100.00 \\
\hline 2 & Days to 50\% flowering $\left(\mathrm{X}_{2}\right)$ & 1.59 & 13.10 \\
\hline 3 & Plant height $(\mathrm{cm})\left(\mathrm{X}_{3}\right)$ & 5.81 & 47.88 \\
\hline 4 & $\begin{array}{l}\text { Number of productive tillers per } \\
\text { plant }\left(\mathrm{X}_{4}\right)\end{array}$ & 2.90 & 23.90 \\
\hline 5 & Ear length $(\mathrm{cm})\left(\mathrm{X}_{5}\right)$ & 1.73 & 14.22 \\
\hline 6 & Ear weight $(\mathrm{g})\left(\mathrm{X}_{6}\right)$ & 1.47 & 12.08 \\
\hline 7 & Carotene $(\mathrm{mg} / 100 \mathrm{~g})\left(\mathrm{X}_{7}\right)$ & 3.17 \\
\hline 8 & 1000 grain weight $(\mathrm{g})\left(\mathrm{X}_{8}\right)$ & 0.38 & 0.74 \\
\hline 9 & Crude protein percent $(\mathrm{mg} / 100 \mathrm{~g})\left(\mathrm{X}_{9}\right)$ & 0.09 & 9.55 \\
\hline 10 & Calcium content $(\mathrm{mg} / 100 \mathrm{~g})\left(\mathrm{X}_{10}\right)$ & 1.16 & 12.73 \\
\hline 11 & $\mathrm{X}_{3} \mathrm{X}_{4}$ & 1.55 & 134.03 \\
\hline 12 & $\mathrm{X}_{1} \mathrm{X}_{3} \mathrm{X}_{4}$ & 16.27 & 141.29 \\
\hline 13 & $\mathrm{X}_{1} \mathrm{X}_{2} \mathrm{X}_{4} \mathrm{X}_{5}$ & 17.15 & 157.41 \\
\hline 14 & $\mathrm{X}_{1} \mathrm{X}_{2} \mathrm{X}_{3} \mathrm{X}_{5} \mathrm{X}_{6}$ & 19.11 & 164.92 \\
\hline 15 & $\mathrm{X}_{1} \mathrm{X}_{2} \mathrm{X}_{3} \mathrm{X}_{4} \mathrm{X}_{6} \mathrm{X}_{7}$ & 20.02 & 174.55 \\
\hline 16 & $\mathrm{X}_{1} \mathrm{X}_{2} \mathrm{X}_{3} \mathrm{X}_{4} \mathrm{X}_{5} \mathrm{X}_{7} \mathrm{X}_{8}$ & 21.19 & 176.13 \\
\hline 17 & $\mathrm{X}_{1} \mathrm{X}_{2} \mathrm{X}_{3} \mathrm{X}_{4} \mathrm{X}_{5} \mathrm{X}_{6} \mathrm{X}_{8} \mathrm{X}_{9}$ & 21.38 & 176.19 \\
\hline 18 & $\mathrm{X}_{1} \mathrm{X}_{2} \mathrm{X}_{3} \mathrm{X}_{4} \mathrm{X}_{5} \mathrm{X}_{6} \mathrm{X}_{8} \mathrm{X}_{9} \mathrm{X}_{10}$ & 21.39 & 178.56 \\
\hline 19 & $\mathrm{X}_{1} \mathrm{X}_{2} \mathrm{X}_{3} \mathrm{X}_{4} \mathrm{X}_{5} \mathrm{X}_{6} \mathrm{X}_{7} \mathrm{X}_{8} \mathrm{X}_{9} \mathrm{X}_{10}$ & 21.86 & \\
\hline
\end{tabular}

